\title{
Triiodothyronine regulates cell growth and survival in renal cell cancer
}

\author{
ANNA M. CZARNECKA ${ }^{1}$, DAMIAN MATAK ${ }^{1,2^{*}}$, LUKASZ SZYMANSKI ${ }^{1,3^{*}}$, KAROLINA H. CZARNECKA ${ }^{4}$, \\ SLAWOMIR LEWICKI $^{5}$, ROBERT ZDANOWSKI ${ }^{5}$, EWA BRZEZIANSKA-LASOTA ${ }^{4}$ and CEZARY SZCZYLIK ${ }^{1}$ \\ ${ }^{1}$ Department of Oncology with Laboratory of Molecular Oncology, Military Institute of Medicine; \\ ${ }^{2}$ School of Molecular Medicine, Medical University of Warsaw; ${ }^{3}$ Institute of Genetics and Biotechnology, \\ Faculty of Biology, Warsaw University, Warsaw; ${ }^{4}$ Department of Molecular Bases of Medicine, \\ Medical University of Lodz, Lodz; ${ }^{5}$ Department of Regenerative Medicine, \\ Military Institute of Hygiene and Epidemiology, Warsaw, Poland
}

Received May 20, 2016; Accepted July 25, 2016

DOI: $10.3892 /$ ijo.2016.3668

\begin{abstract}
Triiodothyronine plays an important role in the regulation of kidney cell growth, differentiation and metabolism. Patients with renal cell cancer who develop hypothyreosis during tyrosine kinase inhibitor (TKI) treatment have statistically longer survival. In this study, we developed cell based model of triiodothyronine (T3) analysis in RCC and we show the different effects of T3 on renal cell cancer (RCC) cell growth response and expression of the thyroid hormone receptor in human renal cell cancer cell lines from primary and metastatic tumors along with human kidney cancer stem cells. Wild-type thyroid hormone receptor is ubiquitously expressed in human renal cancer cell lines, but normalized against healthy renal proximal tube cell expression its level is upregulated in Caki-2, RCC6, SKRC-42, SKRC-45 cell lines. On the contrary the mRNA level in the 769-P, ACHN, HKCSC, and HEK 293 cells is significantly decreased. The TR $\beta$ protein was abundant in the cytoplasm of the 786-O, Caki-2, RCC6, and SKRC-45 cells and in the nucleus of SKRC-42, ACHN, 769-P and cancer stem cells. T3 has promoting effect on the cell proliferation of HKCSC, Caki-2, ASE, ACHN, SK-RC42, SMKT-R2, Caki-1, 786-0, and SK-RC-45 cells. Tyrosine kinase inhibitor, sunitinib, directly inhibits proliferation of RCC cells, while thyroid hormone receptor antagonist 1-850 (CAS 251310-57-3) has less significant inhibitory impact. T3 stimulation does not abrogate inhibitory effect of sunitinib.
\end{abstract}

Correspondence to: Dr Anna M. Czarnecka, Laboratory of Molecular Oncology, Department of Oncology, Military Institute of Medicine, Szaserow 128, 04-141 Warsaw, Poland

E-mail: anna.czarnecka@gmail.com

*Contributed equally

Key words: triiodothyronine, renal cell cancer, sunitinib, thyroid hormone receptor
Renal cancer tumor cells hypostimulated with T3 may be more responsive to tyrosine kinase inhibition. Moreover, some tumors may be considered as T3-independent and present aggressive phenotype with thyroid hormone receptor activated independently from the ligand. On the contrary proliferation induced by deregulated VHL and or c-Met pathways may transgress normal T3 mediated regulation of the cell cycle.

\section{Introduction}

Multiple reports in the field or endocrine oncology have shown that in renal cell cancer (RCC) development and progression stimulation by estrogens, androgens, testosterone, aldosterone, or glucocorticoids are significant pathogenesis factors (1-3). In molecular research, disturbances in the 3,5,3'-triiodotyronine (T3) signaling pathway were described as a possible trigger in RCC (4). In clinical reports, an increased risk of kidney cancer was reported in women with a history of hypothyroidism with myxedema, thyrotoxicosis (5) or multinodular thyroid disease (6). The molecular background of coincidence or codependence of renal cell cancer and thyroid disease is elusive.

In general, the signaling of thyroid hormones (THs), including $\mathrm{T} 3$, is mediated by $\mathrm{TH}$ receptors (TRs) TR $\alpha$ (isoforms $\alpha 1$ and $\alpha 2$ ) and $\operatorname{TR} \beta$ (isoforms $\beta 1$ and $\beta 2$ ). In cell biology, TRs function as T3-inducible transcription factors. By controlling the expression of specific genes, THs regulate a panel of biological processes, including embryonic and postnatal development, animal/human metabolism, and general organism-cell homeostasis (7). THs influence sodium and calcium reabsorption and renal potassium permeability, and they affect renin release and angiotensinase activity $(8,9)$. At the tissue and cell levels, THs regulate differentiation, proliferation, and apoptosis (10). In normal kidneys, THs have been shown to play a role in renal morphogenesis and growth regulation, renal cell differentiation, and renal cell proliferation (11). It was also reported that T3 increased the expression of the epidermal growth factor receptor (EGFR) gene in renal tubule cells and as a result it potentiated mitogenic stimulation of epidermal growth factor (EGF) (12). Data on the function 
of TRs and impact of T3 on renal cancer is not as detailed as for the healthy kidney and relevant in vitro and in vivo models need to be developed.

In humans, the normal total T3 value is $1.2-3.4 \mathrm{nmol} / \mathrm{l}$ or 80-230 ng/dl, depending upon the assay conditions and the antibody employed (13). The normal range of serum-free T3 (active form) is 3.0-7.0 pg/ml, as derived from mass values using a molar mass of $650.98 \mathrm{~g} / \mathrm{mol}$. At physiological concentrations, the total free hormone value of T4 and T3 is $\sim 0.03$ and $0.20-0.4 \%$, respectively. It results in $6 \mathrm{pM}$ of $\mathrm{T} 3$ and $30 \mathrm{pM}$ of T4 (14). In serum, $0.3 \%$ of T3 is free, and $70-80 \%$ of $\mathrm{T} 3$ production is accounted for by peripheral conversion of T4 to T3. One-third of circulating T4 is converted to T3 in peripheral tissues. Tissues in need of TH convert T4 to T3 at different rates (15). T3 is produced by extra-thyroidal conversion of T4 by 5 '-mono-deiodinase, including type I (5'DI), which is highly expressed in the kidneys (16). The expression of 5'DI was reported to be downregulated in $\mathrm{RCC}$ in comparison to that observed in normal kidneys (17). Furthermore, RCC patients treated with tyrosine kinase inhibitors who develop hypothyroidism are expected to have longer progression-free survival (PFS) and overall survival (OS) (18-20). This observation urge the question if the direct influence of T3 on renal cell cancer cells is involved in the mechanism of disease control or if there is no direct cause-effect and just a correlation of phenomena.

In cancer THs promote cancer cell proliferation, tumor angiogenesis, and neovascularization via $\operatorname{TR} \beta$ and activation of its signaling pathway (21). As reported earlier, upon stimulation of TR $\beta$, cells secreted vascular endothelial growth factors and basic fibroblast growth factor $(22,23)$. THs were also shown to play a role in promoting radiation- and chemical-induced carcinogenesis $(24,25)$. TR gene deletions, mutations, and methylation and deregulated expression of TRs protein have been shown to be associated with the development of multiple types of cancer, including hepatocellular carcinoma (HCC), breast, colon, lung, and prostate cancers $(26,27)$. As a result, TRs have been designated as tumor suppressors. Cancer-promoting effects of THs are mediated by downstream TR signaling and by integrin $\alpha_{\mathrm{v}} \beta_{3}$ signaling via phosphatidylinositol-3-kinase (PI3K) and mitogen-activated protein kinases (MAPK), focal adhesion kinase (FAK) and the Src tyrosine kinases. This cell-signaling results in stimulation of angiogenesis in the tumor (26). Indeed, tetraidothyroacetic acid (TETRAC), a thyromimetic agonist of TR $\beta$ that can also block the T4 integrin $\left(\alpha_{v} \beta_{3}\right)$ receptor at the cell surface, has been shown to inhibit growth of human renal cell carcinoma xenografts (28). In the case of renal cell cancer abnormal T3 signaling was also reported to induce overexpression of E2F transcription factor 1 and cyclin E1 and trigger undesirable G1/S phase progression (4), while other functional data on T3 and RCC is currently not available.

The THRB (thyroid hormone receptor gene) has been in the focus of RCC-related research because it is located on the short arm of chromosome 3 , in the proximity of the VHL locus, a gene that is commonly mutated in clear-cell RCC (17). The region of common allelic losses (VHL gene) in sporadic RCC is bordered by D3S2 marker and THRB loci and it was in the focus of early VHL-related research (29). A loss of heterozygosity $(\mathrm{LOH})$ analysis provided the first genetic data supporting the significance of THRB in the devel- opment of RCC, with the analysis revealing that more that $60 \%$ of non-familial RCCs harbored 3p22-24.1 loss or other $T H R B$ abnormalities (30). Large deletions of $T H R B$ in ccRCC samples were confirmed recently in whole genome analyses including The Cancer Genome Atlas Research Network study $(31,32)$. Furthermore, point mutations in TR genes resulting in the loss of its expression have been reported in RCC tumor samples (33). Most TR mutations found in RCC cells result in the expression of a receptor protein with abnormal hormone binding or co-regulator binding potential. Mutated receptor proteins also harbor dominant negative effect against wildtype copy of the receptor. In particular mutant receptor T3 was shown to have affinity shifted towards selected splice forms of silencing mediator of retinoid and thyroid receptors (SMRT) known also as thyroid-, retinoic-acid-receptor-associated co-repressor $(34,35)$. Selected TR mutants, found in RCC cells, were also reported to have disturbed TH response element binding and on the other hand expanded target gene specificity $(34,36-38)$. In addition to large deletions, the epigenetic silencing of the THRB gene was also investigated in RCC samples, but results were negative $(31,39)$. Apart from genomic alternations in THRB gene, the expression of TRs was also shown to be deregulated at the mRNA level $(40,41)$. In addition to the protein coding mRNA sequence, untranslated regions (UTRs) were also shown as mutated. Also these mutations play a significant role in the pathogenesis of RCC, since mutations of the TR $\beta 1$ 5'UTRs resulted in acquisition of new regulatory functions of 5'UTRs. Specific motifs of 5'UTRs and its secondary structures that modulate or/and restrain translation efficiency. In the 3'UTR of TR $\beta$ mRNA specific set of microRNAs is bound and affects its level through RNA interference (RNAi) mechanism and modify THRB gene translation. This set of miRNA is different in mutated cases $(39,41)$. At this point of time analysis of T3 stimulation responsiveness in renal cell cancer cells with mutated and/or wild-type $T H R B$ is not directly available since current reports were derived from data obtained from the investigation of frozen RCC tissue samples $(33,40,41)$, transfected adult African green monkey cells (CV-1 cells) (35) or hepatocellular carcinoma (Hep2G) cells (38). Direct analysis of RCC cell T3 stimulation is missing. The goal of this research was to describe the effect of T3 on RCC cells in in vivo relevant model including physiological concentrations of hormones. The second goal of the analysis was to correlate $\mathrm{T} 3$ response with expression and mutation status of hormone receptor.

\section{Materials and methods}

Cell culture. Human kidney cancer stem cells (HKCSC, RCC-CSCs) were obtained from Celprogen Inc. (Torrance, CA, USA). 786-0 (CRL-1932), Caki-1 (HTB46), Caki-2 (HTB-47), 769-P (CRL-1933), ACHN (CRL-1611), primary normal renal proximal tubule epithelial cells (PCS400010), and 293 [HEK-293] (CRL-1573) cell lines were obtained from ATCC Global Bioresource Center (Manassas, VA, USA). SK-RC-42, SK-RC-44, SK-RC-45, metastatic RCC cell lines were established in the laboratory of Dr Lloyd Old, from patients undergoing nephrectomy at Memorial Hospital of Memorial Sloan Kettering Cancer Center and were obtained from MSKCC core facility (42). Cell lines SMKT-R2 and 
SMKT-R3 were a kind gift from Professor Taiji Tsukamoto (School of Medicine, Sapporo Medical University, Sapporo, Japan) (43). RCC6 cell line was a kind gift of Professor Salem Chouaib (INSERM, Institut Gustave Roussy, Villejuif, France) (44).

Human kidney cancer stem cells (HKCSC, RCC-CSCs) (Celprogen) have been cultured in human kidney cancer stem cell media according to the manufacturer's protocol. In reference experiment RCC cells were cultured in RPMI-1640 with GlutaMAX (Life Technologies, Carlsbad, CA, USA) with $10 \%$ FBS (Biochrom GmbH, Cambridge, UK). For hormone-level controlled experiment cells were cultured in Gibco ${ }^{\circledast}$ FreeStyle $^{\mathrm{TM}} 293$ expression medium (Thermo Fisher Scientific, Waltham, MA, USA), as it does not require the addition of serum, glutamine, or surfactants, and is T3/T4-free (Patent WO1998008934A1).

Cells were cultured both in normoxia $\left(21 \% \mathrm{O}_{2}\right)$ and hypoxia $\left(2 \% \mathrm{O}_{2}\right)$ conditions. Hypoxia was obtained with SANYO MCO-5M incubator. In parallel cells cultured in normoxic conditions were placed in Forma Scientific 3131 incubator. After thawing cells were cultured in normoxia for first passage for viability analysis and subsequently cultured in hypoxia until final stimulation experiments, not earlier that second passage after oxygen tension stabilization.

Hormonal stimulation. For hormonal stimulation 3,3',5-triiodoL-thyronine sodium salt (Sigma-Aldrich, St. Louis, MO, USA) was used. TSH, T3, T4 depleted serum (SF231-2, BBI Solutions, Cardiff, UK) was used as a control. To block the receptor CAS 251310-57-3, thyroid hormone receptor antagonist 1-850 (Santa Cruz Biotechnology Inc. Dallas, TX, USA) was used as it is a cell-permeable hydrazinyl-carboxamide, selective and high-affinity thyroid receptor antagonist, blocking T3 (L-triiodothyronine)-mediated interaction of receptor with nuclear receptor co-activator and blocking downstream targeted gene expression. For drug toxicity sunitinib malate and DMSO (Sigma-Aldrich) were used. For hormone effect cells were cultured in RPMI 10\% FBS. For high T3 stimulation cells were cultured in RPMI 10\% FBS with addition of $1 \mathrm{pM} \mathrm{T3}, 4 \mathrm{pM} \mathrm{T3}, 1 \mathrm{nM}$ T3 or $100 \mathrm{nM} \mathrm{T3}$. As negative control RPMI 10\% FBS with inhibitor T3 was used. Inhibition effectivity was estimated in RPMI $10 \%$ FBS with inhibitor T3 and $4 \mathrm{pM}$ T3. A control, hormone-free conditions, RPMI with T3 depleted serum was used. For additional T3/T4 stimulation experiments cells were cultured in FreeStyle medium - animal origin-free, protein-free and chemically-defined medium. This medium contains L-alanyl-L-Glutamine, amino acids, vitamins, and salts. T3 stimulation was obtained in FreeStyle medium with $1 \mathrm{pM} \mathrm{T3,4} \mathrm{pM}$ T3, $1 \mathrm{nM}$ T3 or $100 \mathrm{nM}$ T3. As a negative control FreeStyle with $1.5 \mu \mathrm{M}$ T3 inhibitor was used. Inhibition effectivity was confirmed in FreeStyle medium with $1.5 \mu \mathrm{M}$ inhibitor $\mathrm{T} 3$ and $4 \mathrm{pM}$ T3. Tyrosine kinase and hormone cross effect on RCC cells was tested in FreeStyle medium with $3 \mu \mathrm{M}$ sunitinib and $1 \mathrm{pM} \mathrm{T3,4} \mathrm{pM}$ T3, $1 \mathrm{nM}$ T3 or $100 \mathrm{nM} \mathrm{T3}$. Drug toxicity against RCC cells was tested in FreeStyle medium with $3 \mu \mathrm{M}$ sunitinib. FreeStyle with DMSO was used as control of toxicity.

Cell viability analysis. AlamarBlue ${ }^{\circledR}$ (Life Technologies) was used to estimate cell proliferation, hormone stimulation and drug toxicity. Alamar blue measurements were performed every $24 \mathrm{~h}$ for $6 \mathrm{~h}$ with Multiskan ${ }^{\mathrm{TM}} \mathrm{GO}$ microplate spectrophotometer (Thermo Fisher Scientific). Cell viability and number was also confirmed with automated cell counter 'MOXI Z' (Orflo Technologies, Ketchum, ID, USA). Vybrant ${ }^{\circledR}$ MTT cell proliferation assay kit (Thermo Fisher Scientific) was used as a method for determination of cell number using microplate reader. MTT based determination of cell growth rate was used in the testing of $\mathrm{T} 3$ stimulation.

Colony formation analysis. The influence of $\mathrm{T} 3$ on cell anchorage-independent growth was analyzed with Cell Recovery Compatible StemTAG ${ }^{\mathrm{TM}}$ stem cell colony formation assay (Cell Biolabs, Inc. San Diego, CA, USA) according to the manufacturer's protocol with adjustment to differential hormone concentration in media. Cell lines were cultured in layers of base agar matrix, cell suspension/agar matrix, and culture media with/without T3 in 96-well plates. The differences of potency to generate various sizes and numbers of colonies between the cell lines was analyzed with a dissecting microscope Delta Optical SZ-450T (Delta Optical, Nowe Osiny, Poland) and an inverted microscope Olympus CKX41 (Shinjuku, Tokyo, Japan).

Cell cycle analysis. Cell cycle phase determination kit (Cayman Chemical, Ann Arbor, MI, USA) was used according to the manufacturer's protocol, including propidium iodide staining. For hormone stimulated cell cycle evaluation, cells were cultured in FreeStyle medium in 6-well plates and cultured with or without $4 \mathrm{pM} \mathrm{T} 3$ for $72 \mathrm{~h}$ after seeding. Flow cytometry analysis was performed with FACSCalibur instrument (Becton-Dickinson and Co., Franklin Lakes, NJ, USA). Analysis was performed with FlowJo single cell analysis software (FlowJo, LLC, Ashland, OR, USA).

DNA sequencing. Sequencing service (Genomed S.A, Warsaw, Poland) was used to analyze THR $\beta$ coding sequence (reference: CCDS ID CCDS2641.1). Reference sequence analyzed was refereed as to wild-type (non-mutated) $(45,46)$. Total RNA was isolated with Total RNA Mini Plus kit (A\&A Biotechnology, Gdynia, Poland) and quantified by Multiskan ${ }^{\mathrm{TM}}$ GO microplate spectrophotometer (Thermo Fisher Scientific). For reverse transcription of RNA TranScriba-qPCR master mix SYBR kit with moloney murine leukemia virus (MuMLV) reverse transcriptase and oligo-(dT) primer was used (A\&A Biotechnology). Sequencing primers were designed to cover all transcript variants including: NM_000461.4, NM_001128177.1, NM_001128176.2 and NM_001252634.1. Primers used were as follows: THRBF1, ATG+ACTCCCA ACAGTATGACAGA;THRBR1,GGCAAAATCCACCACTC TGG; THRBF2, AGTCAATGCCCCAGAAGGTG; THRBR2, CTAATCCTCGAACACTTCCAAGA. Sequences were analyzed with CLC Sequence Viewer program ver. 7.0.2 (Qiagen, Waltham, MA, USA).

RT Real-Time PCR analysis. RT-qPCR reactions were performed with FastStart essential DNA green master kit (Roche Applied Science, Penzberg, Germany) using the LightCycler ${ }^{\circledR}$ Nano Instrument. Expression of thyroid hormone receptor $\alpha$ and $\beta$ along with reference gene peptidylprolyl 
isomerase A (Cyclophilin A) - PPIA - were analyzed with subsequent primers: THRB-R,CACAGAGCTCGTCCTTGTC TAAGTAA; THRB-F, GTGTCTCAAGTGCCCAGACCTT; THRA-F, TGGATGACACGGAAGTGGCTCT; THRA-R, ACGCCTCCTGACTCTTCTCGA; PPIA-F, TGTGTCA GGGTGGTGACTTC; PPIA-R, TTGCCATGGACAAGA TGCCA.

Western blot analysis. NE-PER Nuclear and Cytoplasmic Extraction kit (Thermo Fisher Scientific) was used to isolate protein fractions and quantified with bicinchoninic acid (BCA) protein assay (Sigma-Aldrich, St. Louis, MO, USA). Thyroid hormone receptor $\beta$ - 1 antibody [J52] (Thermo Fisher Scientific) was used for analysis $(1: 1,150)$. For cytoplasmic isolates $\beta$ actin loading control antibody [BA3R] Thermo Fisher Scientific) and for nuclear extracts histone H3 antibody [E.960.2] (SigmaAldrich) were used as control $(1: 1,150)$. Secondary anti-mouse IgG (whole molecule)-alkaline phosphatase labeled antibody produced in goat [A3562] $(1: 7,000)$ was used and detected with SigmaFast ${ }^{\mathrm{TM}}$ BCIP/NBT (5-bromo-4-chloro-3-indolyl phosphate/nitro blue tetrazolium) (Sigma-Aldrich, St. Louis, MO, USA).

Statistical analysis. Statistical analysis was performed in GraphPad Prism 6 (GraphPad Software, Inc., La Jolla, CA, USA). Statistical models for repeated measures were used. In particular growth curves were compared with two-way ANOVA followed with Dunnett's multiple comparisons test and Tukey's multiple comparisons test as statistical methods that allow estimation of inter-individual variability in intraindividual patterns of change over time (47). Cell cycling (cell cycle phase distribution) was evaluated with t-test. Gene expression level (RT-qPCR) was also evaluated with t-test (48).

\section{Results}

Hormonal stimulation of cell viability and proliferation. Normal human renal epithelial cells (ASE-5063) are slow proliferators in comparison to RCC cells. Normal renal cells were responsive to stimulation with $\mathrm{T} 3$ and proliferated at a higher rate when stimulated with $\mathrm{T} 3$, both $\mathrm{T} 3$ from FBS (equivalent to regular serum concentration) and $\mathrm{T} 3$ added to hormone-depleted serum. ASE-5063 cells cultured with the T3 inhibitor proliferated more slowly than when cultured with FBS or T3. There was no difference in the viability of the ASE cells cultured in different concentrations of the T3 hormone. Exposure to $1 \mathrm{pM}$ of T3 stimulated proliferation of ASE-5063 cells at a high rate. The viability and proliferation of primary renal proximal tubule epithelial cells (PCS400010) required $10 \mathrm{nM}$ of supplementation with $\mathrm{T} 3$ in the medium.

In the first step, T3-hyperstimulation was excluded to influence RCC cells viability, both in normoxia and hypoxia (Fig. 1), as the proliferation rate was specific to the cell line and not dependent on additional $\mathrm{T} 3$ stimulation in the hormone-reach medium. Among the cancer cell lines in the hormone-depleted medium, the serum proliferation rate of the HKCSC, Caki-2, ASE, ACHN, SK-RC-42, SMKT-R2, Caki-1, 786-0, and SK-RC-45 cells was decreased. The RCC6, 769-P, and SK-RC-42 cancer cells and the embryonic HEK-293 cells
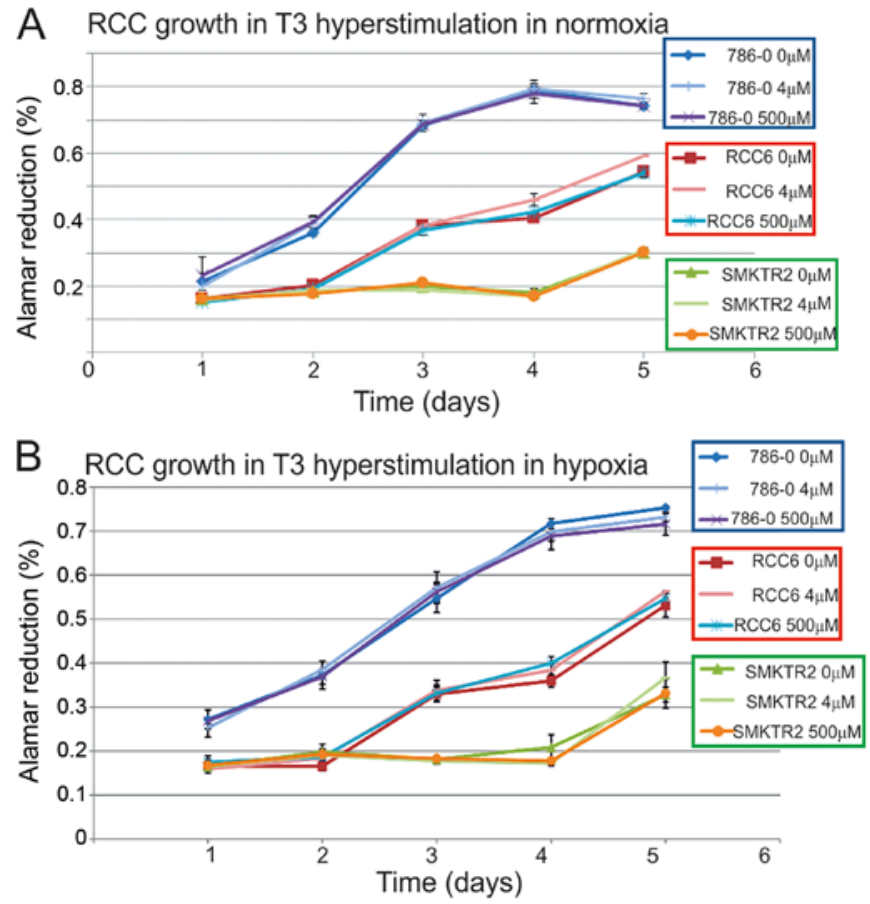

Figure 1. RCC cells viability with T3 hyperstimulation in normoxia and hypoxia (Alamar Blue assay).

were viable and proliferated at a similar rate, both with and without T3/T4. In hormone depleted conditions supplemented $4 \mathrm{pM}$ T3 was not able to stimulate cancer cells to regular proliferation, and only triiodothyronine $-0.56-2.23 \mathrm{ng} / \mathrm{ml}$ with thyroxine T4 - 0.08-0.16 ng/ml induced the cells. Off-theclot serum, thyroxin, triidothyronine and thyroid hormone, depleted and was more effective in decreasing cell viability than thyroid hormone receptor antagonist CAS 251310-57-3 or chemically-defined, animal origin-free, chemically-defined, protein-free medium. The HKCSC renal cancer stem cells were particularly sensitive to T3 regulation, as CAS 251310-57-3 decreased their proliferation. Significant influence of T3 on RCC viability was noted in ACHN cells, that were stimulated by T3 and inhibited by CAS 251310-57-3, both in chemicallydefined and hormone-depleted conditions.

At the same time as resazurin (7-hydroxy-3H-phenoxazin3 -one 10-oxide) based cell viability was estimated by measuring oxidation-reduction in mitochondria (aerobic respiration) and since T3 is well known to increase uncoupling and increase aerobic respiration (49), the impact of T3 on cell metabolism was indirectly evaluated. Metabolic and respiration state of the cells was therefore described as influenced by T3, because T3 depletion (hormone depleted serum) decreased readout (aerobic respiration rate) in HKCSC, Caki-2, ASE, ACHN, SK-RC-42, SMKT-R2, Caki-1, 786-0, and SK-RC-45 cells. In parallel activity of $\mathrm{NAD}(\mathrm{P}) \mathrm{H}$-dependent cellular oxidoreductase enzymes, of the cell cytosolic compartment, reflecting the number of viable cells present, was also measured in an MTT assay. This test was used as it is more related to the glycolytic rate per se and thus to NADH production through glycolysis than to respiration. MTT test results confirmed the impact of $\mathrm{T} 3$ on the $\mathrm{RCC}$ cells, with $\mathrm{T} 3$ promoting the glycolytic rate and viability. T3 inductor effect was shown to arise independently 


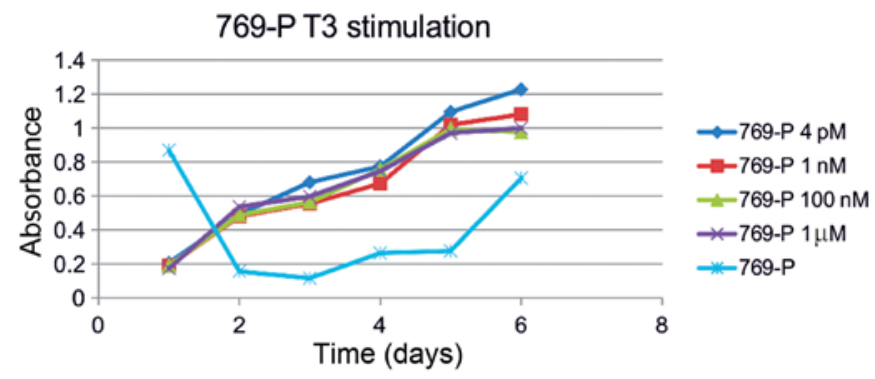

A T3 induction of ccRCC and healthy kidney cells

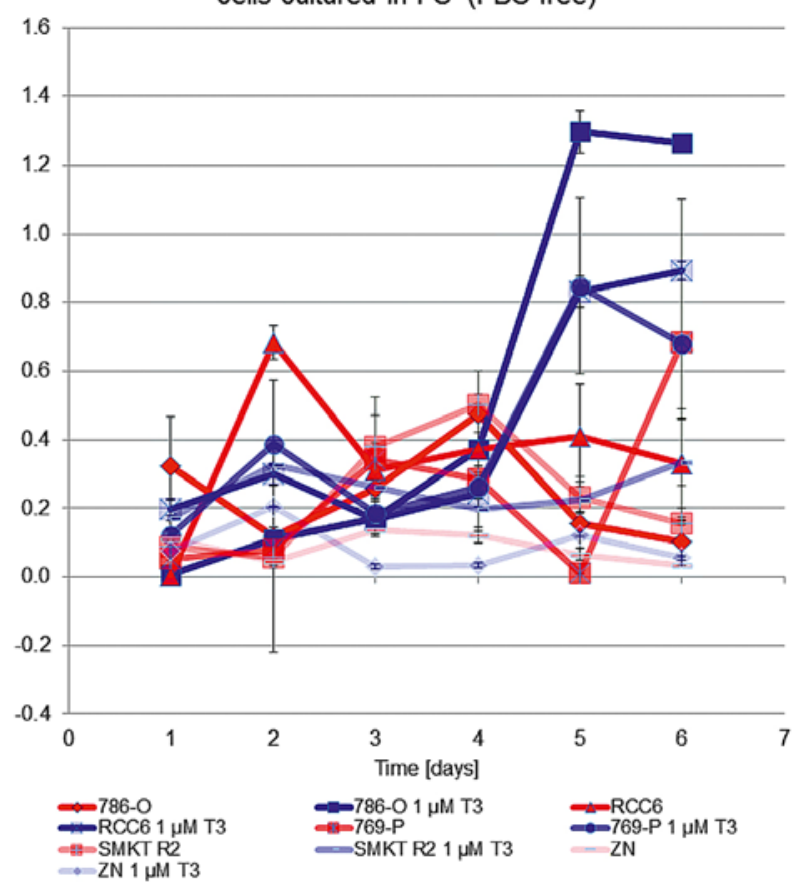

$\rightarrow-$ CAKI-2 $1 \mathrm{nM}$ $\simeq$ CAKI-2 $100 \mathrm{nM}$ $\because \mathrm{CAKI}-21 \mu \mathrm{M}$ $\rightarrow$ CAKI-2

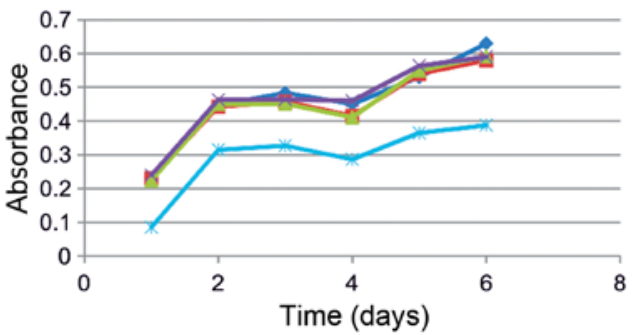

$\rightarrow$ SMKT-R2 4 pM $\rightarrow-$ SMKT-R2 $1 \mathrm{nM}$ $\rightarrow$ SMKT-R2 $100 \mathrm{nM}$ \#-SMKT-R2 $1 \mu \mathrm{M}$ $\because$ SMKT-R2

CAKI-2 T3 stimulation

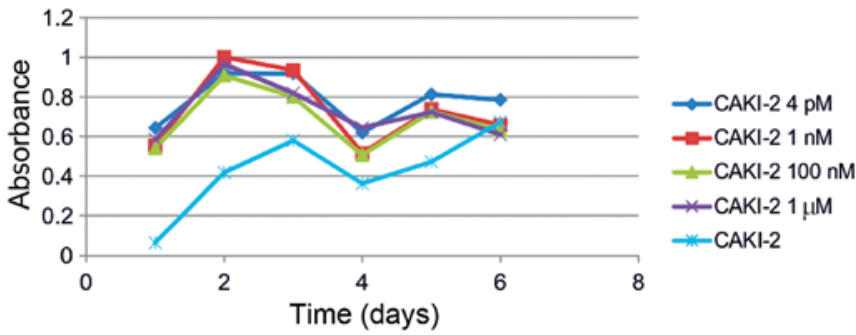

ASE T3 stimulation

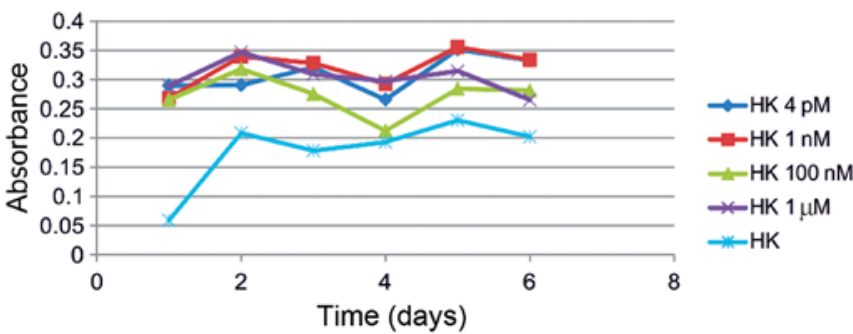

Figure 2. The influence of T3 physiological and supraphysiological concentration on RCC cell viability (MTT assay).

from oxygen pressure in the cell environment (hypoxia versus normoxia) and activate both cells responsive and not responsive to the oxygen concentration (Fig. 2). Hypoxia $\left(2 \% \mathrm{O}_{2}\right)$ promoted viability of Caki-2 cells, normoxia $\left(21 \% \mathrm{O}_{2}\right)$ promoted proliferation of ACHN, and SMKT R2 cells but oxygen partial pressure had no influence on proliferation of 786-O, and RCC6 cells. T3 also promoted the proliferation of 786-0, RCC6, Caki-2, SMKT R2, and healthy kidney cell lines (Fig. 3), as shown in chemically-defined, animal origin-free and chemically-defined, protein-free media. The glycolytic rate and cell viability were also induced by supplementation of as low as 0.5 or $1 \%$ serum in cultures of RCC cells. Additional stimulation with increasing amounts of T3, 4 pM, $1 \mathrm{nM}, 100 \mathrm{nM}$, or $1 \mu \mathrm{M}$, along with serum had no further inductor influence on the RCC cells. Overall, stimulation of the RCC cells with $\mathrm{T} 3 \mathrm{had}$ a greater impact on the glycolytic rate than on oxidative respiration, as shown by comparison of formazan and resazurin oxidation rate. Cultured in the same
B

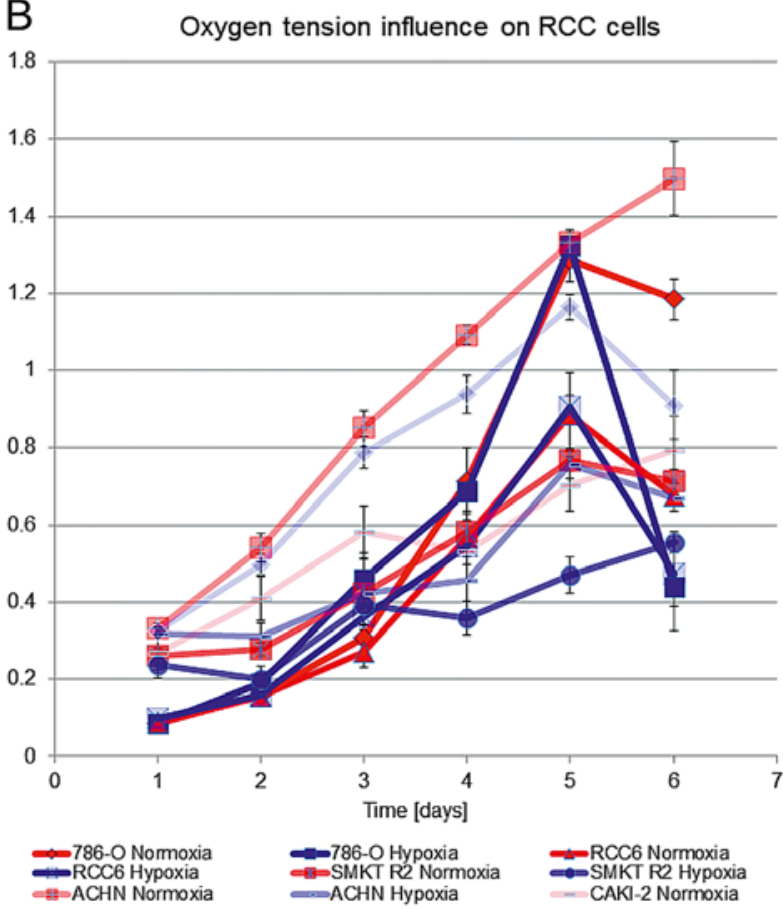

Figure 3. Induction of renal cancer cell proliferation in chemically-defined medium influenced by (A) T3 stimulation and (B) hypoxia or normoxia conditions (MTT assay).

conditions (T3 concentration) RCC cells in the MTT assay were responsive to $\mathrm{T} 3$ stimulation in chemically-defined media, but no difference was shown in Alamar blue measurements (Fig. 2).

After T3 stimulation in most cell lines trend of decreasing number of cells in G1 with concurrent increasing in S phase was observed ( $p>0.5$ ) (Table I and Fig. 4). The opposite correlation was observed in the ACHN and 786-0 cell lines $(\mathrm{p}<0.5)$. 
Table I. Cell cycle distribution before and after T3 stimulation.

\begin{tabular}{|c|c|c|c|c|c|c|c|}
\hline Phase & Control & $+\mathrm{T} 3$ & $\%$ change & Phase & Control & $+\mathrm{T} 3$ & $\%$ change \\
\hline \multicolumn{4}{|c|}{ 786-O } & \multicolumn{4}{|c|}{ ACHN } \\
\hline G1 & 87.2 & 90.6 & $+3.4^{\mathrm{a}}$ & G1 & 61.3 & 63.9 & $+2.6^{\mathrm{a}}$ \\
\hline G2 & 3.9 & 2.9 & -1 & G2 & 17.2 & 16.2 & -1 \\
\hline $\mathbf{S}$ & 8.9 & 6.5 & -2.4 & $\mathbf{S}$ & 21.5 & 19.9 & -1.6 \\
\hline \multicolumn{4}{|c|}{ 769-P } & \multicolumn{4}{|c|}{ SM-KT-R2 } \\
\hline G1 & 73.7 & 72.7 & -1 & G1 & 75.9 & 75.5 & -0.4 \\
\hline G2 & 17.9 & 18.8 & +0.9 & G2 & 12.6 & 13.4 & +0.8 \\
\hline $\mathbf{S}$ & 8.4 & 8.4 & -0 & $\mathbf{S}$ & 11.6 & 11.1 & -0.5 \\
\hline \multicolumn{4}{|c|}{ RCC6 } & \multicolumn{4}{|c|}{ HKCSC } \\
\hline G1 & 77.9 & 76.3 & -1.6 & G1 & 45.7 & 42.5 & -3.2 \\
\hline G2 & 9.6 & 9.5 & -0.1 & G2 & 21.7 & 17.2 & -4.5 \\
\hline $\mathbf{S}$ & 12.5 & 14.3 & +1.8 & $\mathbf{S}$ & 32.6 & 40.4 & $+7.8^{\mathrm{a}}$ \\
\hline \multicolumn{4}{|c|}{ Caki-2 } & \multicolumn{4}{|c|}{ HSE } \\
\hline G1 & 81.3 & 78.2 & -3.1 & G1 & 87.67 & 86.79 & -0.88 \\
\hline G2 & 5.7 & 6.2 & +0.5 & G2 & 11.37 & 12.02 & +0.65 \\
\hline $\mathbf{S}$ & 12.8 & 15.5 & +2.7 & $\mathbf{S}$ & 0.96 & 1.25 & +0.29 \\
\hline
\end{tabular}

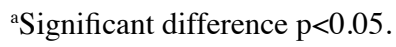

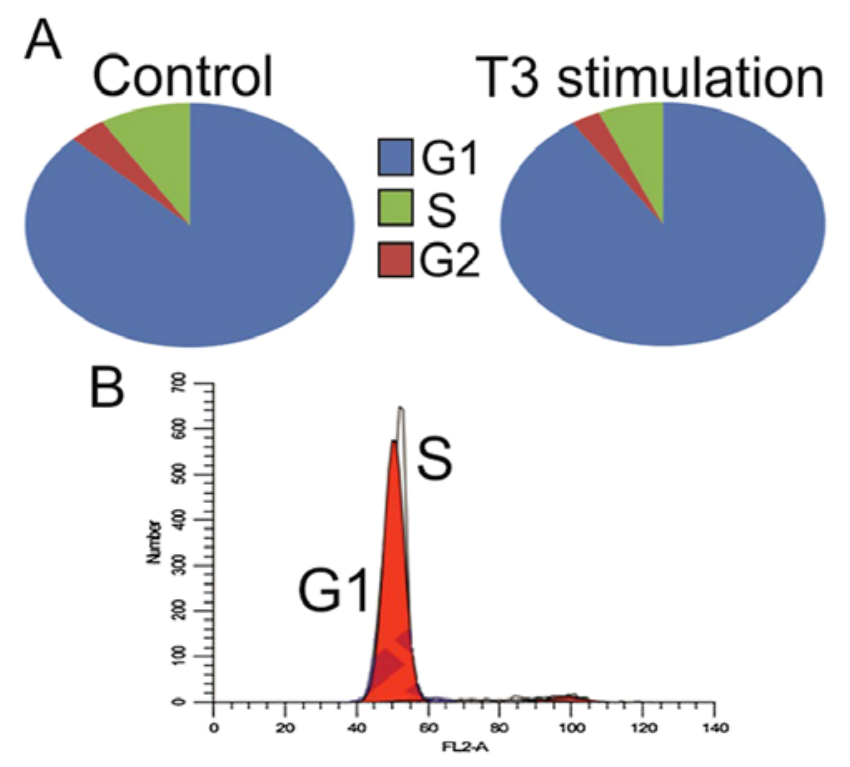

Figure 4. Specific cell cycle phase distribution in 786-0 cell line before and after T3 stimulation.

Interestingly, giving the slow proliferation characteristics of RCC stem cells, there was a significant increase $(+7.8 \%)$ in the number of cells in $\mathrm{S}$ phase in this cell line.

In addition to analyzing cell proliferation in $2 \mathrm{D}$ culture, this study also investigated the impact of $\mathrm{T} 3$ on 3D cell growth.
The colony formation potential of the RCC cells before and after T3 stimulation was low in agar matrix. Only the Caki-2 and SMKT-R2 cells derived from a primary clear-cell carcinoma of the kidney and ACHN cells derived from a metastatic site by pleural effusion generated 3D colonies. The number of colonies formed by the cell lines was not significantly different between the cells stimulated and not stimulated with T3 (Fig. 5). In the soft agar colony formation model of cellular anchorage-independent growth, T3 did not increase the tumorigenic growth potential of the RCC cells in vitro. T3 also had no tumor-suppressive effect on the RCC cells.

Treatment of the normal renal and cancer cell lines with sunitinib, a tyrosine kinase inhibitor, decreased RCC cell growth. T3 stimulation did not promote or prevent the inhibitory effect of sunitinib. Higher T3 concentrations also did not decrease the inhibitory effect of sunitinib.

$T R$ gene sequences and expression. For the analysis THRB gene expression on mRNA and protein level, cell lines were divided into four groups dependent on the origin as follows: primary RCC, metastatic RCC, unclassified renal cells, and control normal kidney cell lines (ASE5063). The statistically significant upregulation of relative expression (RE) was identified in Caki-2, RCC6, SKRC-42, SKRC-45 cell lines, in comparison to normal cells. In contrast, the expression in the 769-P, ACHN, HKCSC, and HEK293 cells was significantly downregulated (Fig. 6). Additional control analysis of the THRA (thyroid hormone receptor $\alpha$ ) expression revealed 


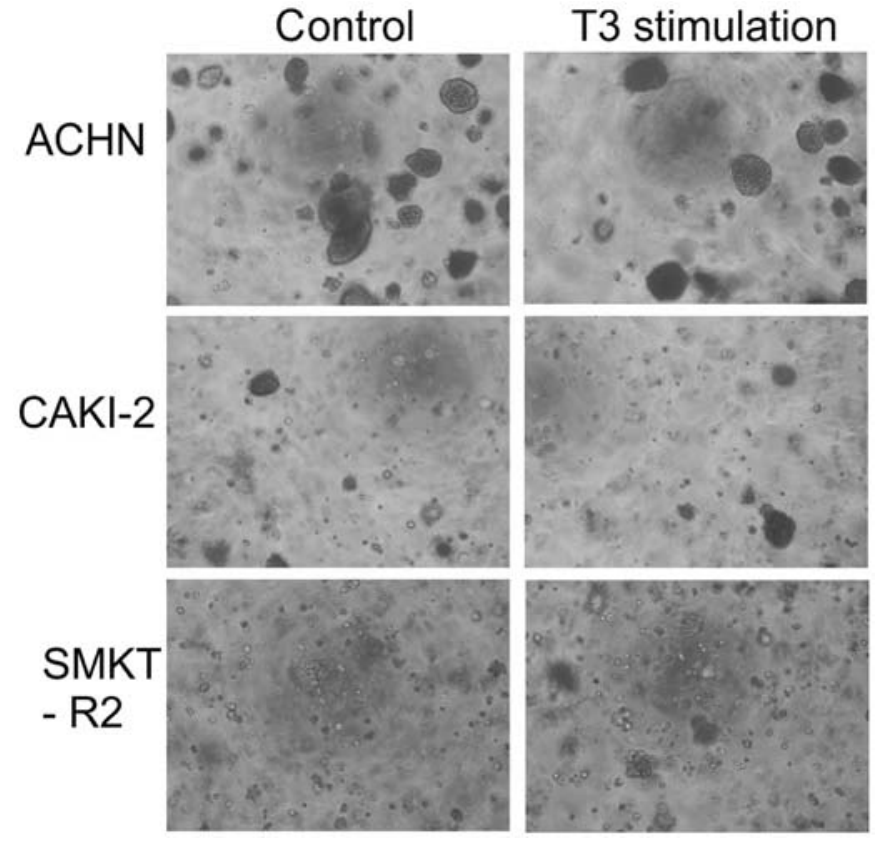

Figure 5. Formation of 3D colonies by renal cell cancer cell lines with and without $\mathrm{T} 3$ induction.

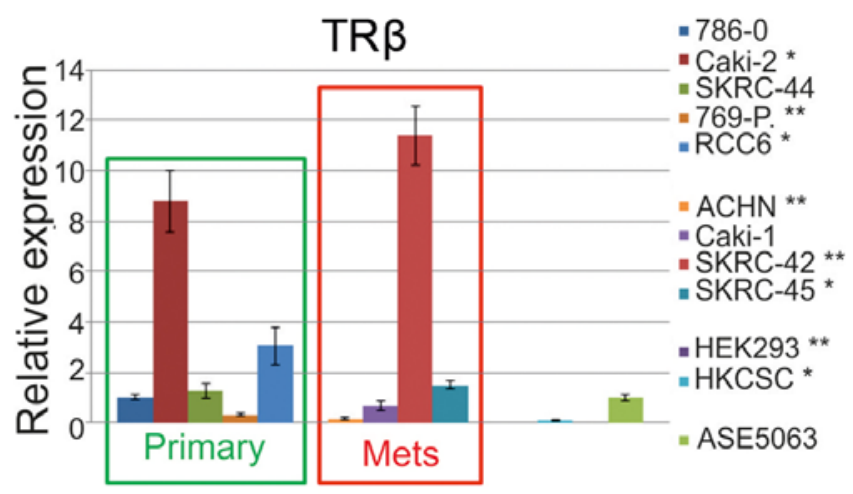

Figure 6. Expression of THRB gene in renal cell cancer cell lines on mRNA level.

significant upregulation in SKRC-44 cells and downregulation in 786-O, 769-P, and RCC6 primary tumor cells (Fig. 7). Among the metastatic cell lines, expression only the in SKRC-44 cells was upregulated, and the expression in all the other cell lines was downregulated. The relative THRA expression in the embryonic renal cell line and renal cancer, cancer stem cells were also downregulated. A subsequent western blot analysis of cytosolic and nuclear proteins confirmed the presence of $\mathrm{TR} \beta 1$ in both fractions. In comparison to normal proximal tubule cells RCC expression and accumulation of TR $\beta 1$ in the cytoplasmic fraction was higher in the 786-O, Caki-2, RCC6, and SKRC-45 cells, than in normal renal cells (Fig. 8). The protein level of TR $\beta 1$ in the SKRC-44 and 769-P primary tumor cells, metastatic ACHN cells, embryonic HEK293 cells, and HKCSC stem cells was downregulated. In cells with a high cytoplasmic level of TR $\beta$, the level of the TR $\beta$ protein in the nuclear fraction was not as high as with the lowest in HKCSC, SKRC-42, ACHN, and 769-P. The analysis showed that the expression levels of mRNA and proteins were corre-

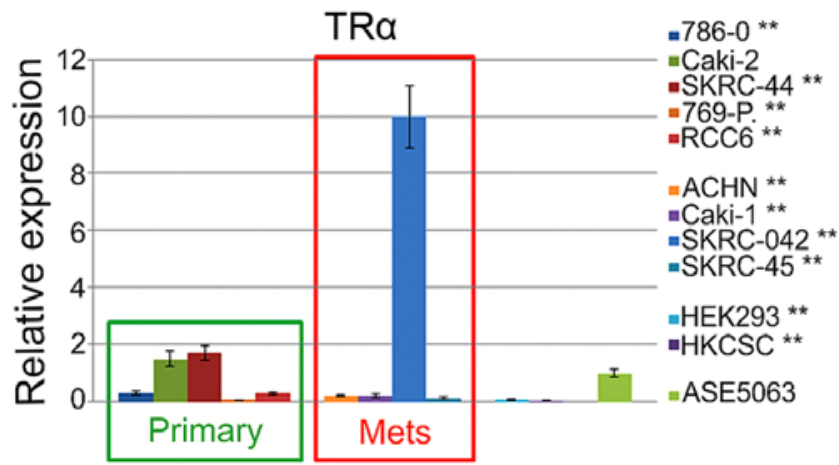

Figure 7. Expression of THRA gene in renal cell cancer cell lines on mRNA level.

Table II. TR $\beta$ gene sequence polymorphisms found in RCC cell lines and their protein consequences.

\begin{tabular}{llll}
\hline Cell line & \multicolumn{1}{c}{ Origin } & Mutation & AA \\
\hline 786-O & Primary & $735 \mathrm{C}>\mathrm{T}$ & F245F \\
SK-RC-42 & Metastatic & $735 \mathrm{C}>\mathrm{T}$ & F245F \\
HEK293 & Human embryonic & $735 \mathrm{C}>\mathrm{T}$ & F245F \\
& kidney & & \\
\hline
\end{tabular}

lated. No difference from reference sequence was found in the analyzed coding sequence of the TR $\beta$ gene and since reference sequence that is referred as normal sequence no mutation was expected. Synonymous polymorphisms were found in three cases (Table II).

\section{Discussion}

The goal of this study was to verify the influence of T3 stimulation on renal cell cancer cells. This research was designed to verify of prolonged survival of hypothyroid RCC patients is epidemiological or cell biology phenomenon. We also aim to verify interaction of T3 and TKI on RCC cells. Understanding the effect of hypothyreosis and normothyreosis on RCC cells is of clinical importance, as hypothyroidism was reported in $>80 \%$ of RCC patients treated with sunitinib (18), up to $20 \%$ of those treated with sorafenib (19), and up to $100 \%$ of those treated with axitinib (50). Furthermore, hypothyroidism was shown to be an independent predictive marker of treatment outcomes in patients with metastatic RCC (20). Hypothyroidism that developed during the treatment of RCC patients was associated with significantly longer progressionfree survival, overall survival, and better objective response rates (51), but hormone replacement with l-thyroxine had no influence on patient survival (52). In a meta-analysis, the observed advantage of acquired hypothyroidism in terms of overall survival was not clear, and the authors indicated that any perceived benefits should be interpreted with caution (53). Data on direct T3 activity in RCC tumor cells was not available. First step undertaken in order to verify the influence of T3 on RCC cell was development of physiologically relevant cell culture model for the study. 
A

Cytoplasmic fraction

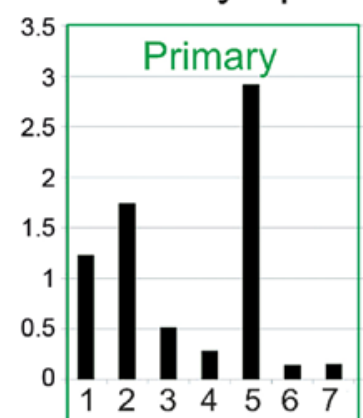

TR $\beta 1$

$\beta$-actin

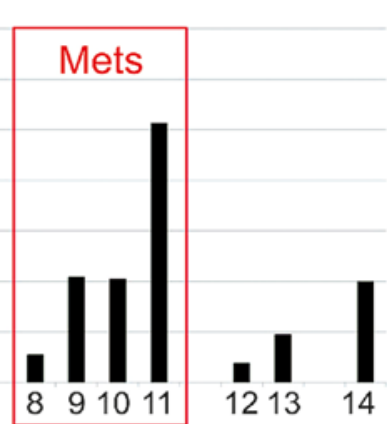

(8)

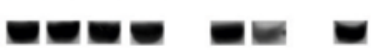

1 - 786-0

2 - Caki-2

3 - SKRC-44

4 - 769-P

5 - RCC6

6 - SMKT-R2

7 - SMKT-R3

$8-\mathrm{ACHN}$

9 - Caki-1

10 - SKRC-42

11 - SKRC-45

12 - HKCSC

13 - HEK293

14 - ASE5063
B

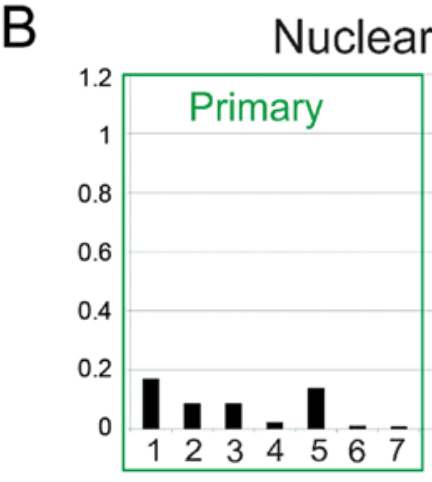

TR $\beta 1$

Histone

H3

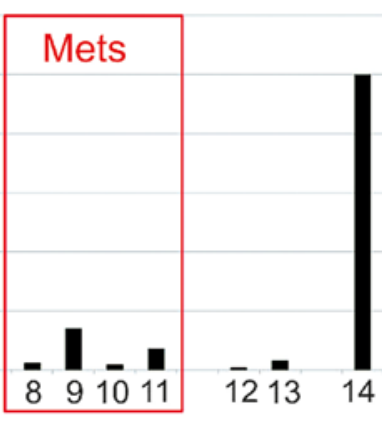

1 - 786-0

2 - Caki-2

3 - SKRC-44

4 - 769-P

5 - RCC6

6 - SMKT-R2

7 - SMKT-R3

8 - ACHN

9 - Caki-1

10 - SKRC-42

11 - SKRC-45

12 - HKCSC

13 - HEK293

14 - ASE5063

Figure 8. TR $\beta 1$ protein expression in (A) cytoplasmic and (B) nuclear fraction of renal cell cancer cells.

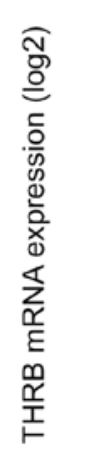

\section{2}

10

8

6

4

2

0<smiles>[Ca][O+]=[Te]</smiles>

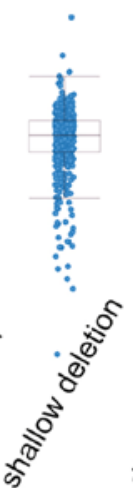
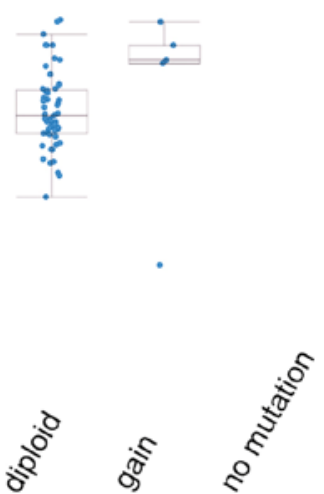

THRB putative copy number alternations (GISTIC)

Figure 9. THRB gene genomic distribution alterations in renal cell cancer including homozygous deletions (deep loss), heterozygous deletion (shallow loss), normal diploid and low-level gain (amplification).

To support the growth of cancer cell lines in vitro generally standard media (RPMI/DMEM/F12), supplemented with fetal bovine/calf serum (FBS/FCS) are used. We confirmed that for modelling of RCC cell physiology FBS, that was used in control experiments, has relevant T3/fT3 concentration for simulation of healthy euthyreosis conditions. The uptake of T4, T3, and reverse (r) T3 by kidney cells is mediated by an active transport process, which is dependent on ATP availability and $\mathrm{Na}^{+}$gradient across kidney cell membrane. Transport of hormones into kidney cells is a rate-limiting step in the metabolism of these THs in the kidney (54). The binding of T3 to the nuclear $\mathrm{T} 3$ receptor of the target cell induces the activity of the hormone. The binding of T3-TR $\beta 1$ complex to the nuclei targets occurs slowly and attains a maximal value after $2-3 \mathrm{~h}$ of induction. The peak effect of T3 mediated gene expression occurs not earlier than 1-2 $\mathrm{h}$ after stimulation with hormone $(12,14)$. In typical cell culture model-based experiments, the T3 hormone binds mitochondrial and cytosol fractions at a concentration in the range of $10^{-12}$ to $10^{-8} \mathrm{M}(1 \mathrm{pM}-10 \mathrm{nM})$, but the nuclear fraction only up to $1-10^{-10} \mathrm{M}(100 \mathrm{pM})$. At higher concentrations of $100 \mathrm{pM}(0.1 \mathrm{nM})$, T3 binds to highcapacity non-specific nuclear sites $(14,55)$. The T3 dissociation constant of the TR (both isoforms) is between $10^{-9}$ and $10^{-10} \mathrm{M}$ (100 pM-1 nM), the half-maximal effective concentration $\left(\mathrm{EC}_{50}\right)$ of the TR is $1-2 \mathrm{nM}$, and the TR mediates TH-regulated gene expression $(35,56)$. T3 binds in vitro translated full-length $\mathrm{TR} \beta$ with an apparent equilibrium $(\mathrm{Kd})$ of $108 \mathrm{pM}$, and the T3-TR saturation curve is characterized by a single component (one-phase exponential growth) (57). In the cortical-collecting tubules of the kidney, T3 at a concentration of $10^{-11} \mathrm{M}(10 \mathrm{pM})$ increased $\mathrm{Na} / \mathrm{K}$-ATPase activity and the trans-epithelial voltage (58), but $\mathrm{T} 3$ at a concentration in the range of $10^{-10}$ to $10^{-7} \mathrm{M}$ had no effect on inducible nitric oxide synthase (iNOS) protein expression in renal cells (59). In addition, $6.5 \mathrm{pg} / \mathrm{ml}$ of 
$\mathrm{T} 3$ were reported to be required for maturation of $\mathrm{CD} 133 / 1^{+}$ papillary renal cells into tubular epithelial cells in the kidney (60). Based on this cell physiology data it may be concluded that $100 \mathrm{pM}-1 \mathrm{nM}$ T3 stimulation is required to investigate the effect of T3 on renal cell cancer cells, as confirmed in this study. Our result is supported by a previous study confirming that FBS was relevant for studying T3-dependent effects in cell culture. In cells cultured in minimal essential medium (MEM) with $10 \%$ TH-depleted FBS, the expression of 3-hydroxy3-methylglutaryl coenzyme A reductase was downregulated by $70.1 \%$. This deregulation of gene expression was normalized when the cells were transferred to medium supplemented with regular FBS or TH-depleted FBS supplemented with $10^{-6} \mathrm{M}$ $\mathrm{T} 3$ for $48 \mathrm{~h}$ (61). However, due to the presence of endogenous THs in FBS/FCS, it is impossible to control the effects of low (physiological and supra-physiological) levels of THs on cells (62). To study the effect of T3/T4 charcoal-stripped FBS, and serum-free chemically defined medium, must be used instead of standard media (63) and concordant physiological T3 amount must be supplemented. Therefore, we analyzed hormonedeprived serum, chemically-defined media with panel of T3 concentrations and focused on $\mathrm{pM}$ and $\mathrm{nM}$ T3 effects (Fig. 1-3). The goal of this model was to mimic conditions of RCC cells in vivo in euthyreosis and hypothyreosis. Before now renal cells were cultured in $100 \mathrm{nM}$ of T3 and this T3 concentration was reported to inhibit the proliferation of a human proximal tubule cell line (HK2) and stimulate proliferation of Caki-2 and Caki-1 cell lines (4). Such a dose of T3 can be considered hyperstimulation, as a physiological T3 dose was defined before as $10 \mathrm{nM}$, and a supraphysiological dose was defined as $100 \mathrm{nM}$ (64). Moreover, it was demonstrated that short (4 days) and prolonged (3 months) exposure to regular $(1.0 \mathrm{nM})$ and supra-normal T3 concentrations $(25.0 \mathrm{nM})$ supports maximal cell growth rates and induces significant increases in global translation rate (65). Along with this $\mathrm{T} 3$ dosing restriction, the research of Rosen et al with $100 \mathrm{nM} \mathrm{T} 3$ must also be interpreted as used to verify the effect of hormonal hyperstimulation of TRs in RCC, but not the effect of physiological T3 concentration found in RCC patients serum (38).

By focusing on in vivo-like T3 supplementation and using more cell lines, this study confirmed that both hyperstimulatory and physiological conditions promote the viability of not only Caki-1 and Caki-2 cells but also that of other cancer cell lines of both clear-cell cancer and papillary cancer subtype (e.g., ACHN, 786-0, RCC-6; Figs. 1-3). Our data are generally in accordance with the findings of Poplawski and Nauman (4). In our study in standard T3 concentration (FBS-derived) normal renal cells (ASE) were not stimulated by addition of supraphysiological T3 up to final concentration of $100 \mathrm{nM}$, while in the study of Poplawski and Nauman (4) normal renal cells (HK-2) were inhibited by $100 \mathrm{nM} \mathrm{T3}$. Moreover, we have confirmed that the depletion of T3 decreases the proliferation of healthy renal cells. We concluded that the difference between HK-2 and ASE-5063, both cell lined derived from normal proximal tube of the kidney, cells should be applied to differences in cell biology between the lines. ASE-5063 cells represent passage $0-2$ of normal cells (primary culture), while HK-2s are proximal tubular cells immortalized by transduction with human papilloma virus 16 (HPV-16) E6/E7 genes (66). It was shown that HPV E6 and E7 proteins are able to directly interact with thyroid hormone receptor (67), and HPV E2 protein interacts with thyroid hormone receptor and with its co-activators GRIP1 (glucocorticoid receptor-interacting protein 1) and Zac1 (zinc-finger protein which regulates apoptosis and cell cycle arrest 1), and as a consequence influence transcriptional activation of TR $\beta 1$ (68). As a result of HPV proteins interaction with thyroid hormone receptor, the TR $\beta 1$ activation in HK-2 cells is to be different that in primary cultures of renal proximal tubule (ASE-5063) cells. We believe that analysis of primary culture represents the in vivo state more closely than investigation of immortalized cells (69).

It is important to consider the mechanism of metabolic regulation in HIF-1 overexpression state in which local TH signaling is reduced through the induction of local thyroxine deiodinase D3 (70). In this study, the supplementation of RCC cells culture with T3 promoted proliferation and oxidative phosphorylation metabolism when compared with T3/ T4-depleted serum (BBI solutions serum or FreeStyle media). T3 promoted the proliferation of RCC cells at a concentration as low as $1 \mu \mathrm{M}$ when compared to T3-free conditions. A concentration of $1 \mu \mathrm{M}$ fT3 represents hypothyroidism, with normal limit being $3 \mu \mathrm{M}$. At the same time, without T3 exogenous supplementation, the RCC cells still proliferated when other chemically-defined factors were present. The lowmolecular weight TR antagonist (CAS 251310-57-3) did not inhibit the prostimulatory effect of $\mathrm{T} 3$ on the RCC cells to any great extent and other inhibitors should be considered in the future. T3 stimulation was not sufficient to overpower the inhibitory effect of sunitinib on the RCC cells, as shown in the Alamar-Blue-based cell viability test. This test was effectively used as cell health indicator and measure of the reducing power of living cells and quantitative measure of cell line proliferation allowing to establish relative cytostimulatory and cytotoxicity of T3, T3-inhibitor, and sunitinib.

In our study the effect of T3 on the cell cycle was dependent on the RCC line, as well as the overall speed of the division of these cells (Table I). Regardless of the genetic variation between the individual tumors from which the cell lines were isolated, the impact of hormonal $\mathrm{T} 3$ induction was possible to describe when the same cell line under controlled conditions of supplementation and deprivation of THs was compared. In this study, T3 stimulation had little impact on the distribution of the cell cycle phase and cell cycle progression of RCC cells. Nevertheless trend of decreasing number of cells in G1 with concurrent increasing in S phase was shown (Table I and Fig. 4). In conclusion, T3 cell cycle regulation changes in the cell cycle may be related to the checkpoint of the cell cycle in the late G1 phase referred as to nutrient-sensing cell growth checkpoint (71) and may depend on the impact of hormonal stimulation on cyclins (72). As the $\mathrm{S}$ and $\mathrm{G} 2 / \mathrm{M}$ phases of mammalian cells are relatively invariant in length, with changing interdivision time, a decrease in the interdivision time due to the increased rate of mass synthesis necessarily leads to a shortening of the G1 phase (72), which is taking place in most investigated RCC cells. Our result are supported by a previous study which has shown that $\mathrm{T} 3$ signaling disturbances result in improper G1/S phase progression in Caki1 and Caki-2 cells (4). These authors have also shown that in RCC T3 regulate proliferation, acting as a stimulator and inhibits of the proliferation of normal immortalized kidney 
(HK2) cells. This difference was explained by T3-deregulated expression of transcription factors E2F4 and E2F5, along with Retinoblastoma-like 1 protein (p107) and retinoblastoma-like 2 protein (p130) activity in cancer cells. E2F4 and E2F5 factors in complexes with p107 or p130 stop cancer cells in G1 phase and repress cell cycle progression and gene transcription. At the same time, p107 and p130 may inhibit the activity of cyclin/cdk2 complexes and promote cell cycling (4). Fibroblast cell cycle analysis showed that the G0/G1 phase transition is mainly affected by $\mathrm{T} 3$ and that number of cells in $\mathrm{S}$ phase is reduced after T3 stimulation (73) and the same phenomenon we observed in RCC cancer stem cells. In cell cycle analysis it should not be forgotten that TR $\beta$ expression levels increase in a cell cycle-dependent manner (74). The levels of TR proteins was also specifically shown to fluctuate in HK2 cells, and increase during cell cycle progression. In contrast, in Caki-2 cells, the expression profile was improper, with protein levels dropping during progression (4). Collectively, we believe that $\mathrm{T} 3$ although significant factor in RCC cell cycle regulation has cancer case to case-specific effect that must be explained by background mutations.

To determine whether T3 signaling was disturbed in studied RCC cells, TH $\beta$ was analyzed at the mRNA and protein levels. Previous studies reported inconsistent data on the expression of TR $\alpha$ and TR $\beta$ in RCC. One study reported that the expression of TR $\beta$ at the mRNA level was upregulated in 30\% and downregulated in $70 \%$ of RCC cases when compared with adjacent normal renal tissue (40). In RCC tissues with THRB underexpression, the measured amount of specific mRNA was $\sim 2.5 \pm 3$ times lower in cancer tissue when compared with the surrounding tissue and $\sim 2.2$ times lower in comparison with that of other healthy kidneys (40). However, investigated kidneys affected by other pathologies, including cysts, which could represent some gene expression abnormalities. The expression levels of mRNA TR $\beta$ were reported to be lower in G1 tumors than in G2 and G3 tumors. Among RCC with TR $\beta$ gene overexpression (6/20 cases), the tumors were mostly poorly differentiated (G2 and G3) and clinically more advanced, including T3b, T3c, and T4b (40). TR $\beta$ mRNA amount was significantly different between tumors and surrounding tissues only in G3 cases. The same study reported that TR $\beta$ mRNA was underexpressed in $33.6,34.2$, and $40.1 \%$ of G1, G2, and G3 tumors, respectively (40). Our results showed that the TR $\beta$ transcript level was decreased in SKRC-44 and 769-P primary tumor cells, metastatic ACHN cells, embryonic HEK293 cells, and HKCSC stem cells, and it was increased in 786-O, Caki-2, RCC6, and SKRC-45 cells when compared to the level in cells derived from healthy kidney proximal tubules. Measurement of the TR $\beta$ transcript revealed cells with high expression (cell line SKRC-42) and low expression (cell lines 769-P, HKCSC, SKRC-45). In the first group, the expression was up to 12 times higher in RCC cells in comparison to that of healthy renal cells. There was no difference in the expression of the TR $\beta$ transcript in papillary RCC cells (i.e., Caki-2, ACHN, and HKCSC) when compared with that of clear-cell RCC (i.e., Caki-1, 786-0, and 796-P). There was also no difference in the expression of the $\operatorname{TR} \beta$ transcript in cells originating from metastatic tumors and those originating from primary tumors. Our results represent therefore additional evidence for TR $\beta 1$ expression deregulation in RCC.
In previous studies an interesting discrepancy between mRNA and protein levels was described, with a low level of protein found in RCC cells with overexpression of TR $\beta$ mRNA (40). In tissue analysis by Master et al (41) TR mRNA and protein levels were reported to be reduced by 70 and $91 \%$, respectively, in ccRCC tissues. This phenomenon was accompanied by an absence of the TR $\beta 1$ target gene, the type 1 deiodinase enzyme (DIO1) protein, and a 58\% reduction in the tissue concentration of T3, which is generated mainly by DIO1. The observed discordance in the magnitude of the change in TR mRNA and protein was explained by the influence of aberrant splicing of TR mRNA 5'UTRs, leading to differences in the translation efficacy and expression of the miRNA-204, inhibitor of TR mRNA 3'UTR. The authors concluded that the $T H R B$ expression in RCC cells is subject to complex post-transcriptional regulation Master et al (41). In our study, the high TR mRNA level was not correlated with a low TR $\beta 1$ protein level in the nuclear fraction, suggesting that nuclear translocation is important for the activity of TR $\beta$. Complementary to our data abnormalities in TR mRNA translation reported in RCC were shown to be cancer specific. In normal renal cells, the major TR transcript contains variant A (AY286465.1) of the 5'UTR. In RCC, this is deregulated. A loss of transcript variants IVS4B (GeneBank: GQ919288.1) and F1 (GQ456950) was reported in ccRCC. A functional analysis of the influence of the 5'UTR variant on protein expression in an RCC cell line, Caki-2, showed that weakly folded variant A promoted the highest level of receptor expression. In contrast, variants F (AY286470.1) or F1 (GQ456950), which were strongly folded, resulted in low transcription, low translation rates, and low receptor expression. In $>70 \%$ of RCC cases, a reduction in the TR $\beta 1$ mRNA coding sequence has been reported. Furthermore, reduced expression of A and F 5'UTR variants has been reported in 75 and $62 \%$ of tumors, respectively (41). Finally TR $\beta 1$ protein level in cancer tissues was barely detectable. An analysis of the protein level of TRs in nuclear extracts from RCC tumors revealed that the TR $\beta 1$ protein level was decreased in $87 \%(20 / 23)$ of tumors when compared with that of normal tissue from the same kidney. The level of the TR $\beta 1$ protein was decreased 1.2-16 times. The expression level of the TR $\alpha 1$ protein was 1.6 times higher in tumors than in healthy tissue, and the expression level of TR $\beta 1$ was 1.7 times lower in tumors than in healthy controls (40). In Caki-2 and Caki-1 cancer cell lines the level of TR proteins was lower than in healthy kidney HK2 cells (4). In this study, we showed a low level of expression of TR $\beta$ in the RCC nuclear fraction compared with that of the healthy kidney cells. The distribution of the cytoplasmic fraction level was more variable, suggesting that the cell localization and activity are altered in RCC and that the cytoplasmic pool represents a quiescent fraction of the protein. In cases with a high cytoplasmic level of TR $\beta$, the level of the TR $\beta$ protein in the nuclear fraction was not as high. This confirms and extends the findings of a previous study, which demonstrated a low level of TR $\beta$ in pseudotriploid cells derived from human embryonic kidney (HEK293) with deregulated cell cycle control pathways and apoptosis but lacking a VHL or c-MET pathway (75).

In this study, the RCC cells did not harbor TR coding sequence differences when compared with those of a standard reference sequence deposited in the NCBI database 
and they did not contain mutations reported previously $(33,54,76)$. In a previous study, TR genes from 22 tumor tissues, 20 corresponding controls, and seven non-cancerous kidney tissues were sequenced and compared with those of a control (wild-type TR $\beta 1$ cloned from non-cancerous kidneys) (33). The authors reported that the mutations were clustered in T3-binding domains (D and E). In particular, one TR $\beta 1$ (3TR $\beta 1)$ mutant was isolated from an RCC grade G1 tumor ( $25 \%$ of all G1 tumors tested), three TR $\beta 1$ (25TR $\beta 1,8 \mathrm{TR} \beta 1$, $18 \mathrm{TR} \beta 1)$ mutants were isolated from G2 (33\%) tumors, and three TR $\beta 1$ (15TR $\beta 1,32 \mathrm{TR} \beta 1,6 \mathrm{TR} \beta 1)$ mutants were isolated from G3 (42.8\%) tumors. In total, nine of all analyzed RCC cases (40.9\%) had at least one mutation in a ligand (T3)-binding domain or DNA-binding domain. Of these mutations, seven were missense, and these were also mostly clustered in T3-binding domains (33). In a subsequent functional analysis, mutant TR $\beta 1$ was shown to have impaired T3 association and DNA binding capacities. The transcriptional activity of many mutants was also reported to be downregulated or lost. Mutations in the T3-binding domains (i.e., Y321H, E299K, $\mathrm{H} 412 \mathrm{R}, \mathrm{L} 456 \mathrm{~S}$, and S380F) reduced the T3 binding activity by $~ 35-60 \%$, and other mutations (i.e., W219L, F451I, F451S, Q252R, A387P, and F417L) resulted in a loss of almost 100\% of T3 binding activity. These mutants also displayed significantly reduced DNA affinity (50-100\%). A mutation in the DNA binding domain (i.e., K155E), which interferes with the TH-response element interaction, resulted in the loss of up to $100 \%$ DNA-binding activity. Furthermore, some mutations (e.g., F415S) exhibited a dominant negative effect on the wild-type TR $\beta$ receptor, and the TR $\beta$ mutants lost receptor transactivation activity. A previous study investigated the effect of mutations found in RCC in a HepG2 cell (HCC) model and performed detailed analyses of the impact of these two mutations on gene regulation (38). The authors showed that the target gene specificity of TR mutants isolated from RCC cells was greatly expanded. The targets of the TR mutants overlapped to a large extent between RCC cases but minimally overlapped with wild-type TR-specific genes or with target genes found in other cancers including HCC. The mutant TR targets included solute carriers, metallothioneins, glycolytic enzymes, and other metabolism genes. In the same study, 69 genes were repressed by a TR $\beta 1$ mutant $(\mathrm{rc} 15-\mathrm{RT} \beta 1=\mathrm{P} 453 \mathrm{~S}$ hormone-binding domain mutant). Although most of the targeted genes were not controlled by the wild-type receptor and were new targets, some of the mutant-repressed genes were activated by the wild-type receptor. The majority of the genes repressed by the mutant receptor were not affected by stimulation or hyperstimulation by T3 and were regulated in a hormone-independent manner. The authors suggested that the different target specificity was the result of changes in the binding of co-activator proteins and therefore the binding of different response elements, broadening the ability of the receptors to recognize different sequences at -1 and -2 positions. As a result, the mutants attained the ability to recognize a distinct set of genes, different from those recognized by the wild-type receptor (38). In the study by Rosen et al (38), other mutations associated with RCC were mostly localized in the DNA-bonding domain and were dominant-negative. These showed altered co-repressor splice variant selectivity and impaired co-repressor release in response to T3 stimulation.
These mutations localized mostly in helix 12 of the receptor and were dominant negative at T3 concentrations of $>10 \mathrm{nM}$, $>100 \mathrm{nM}$, and $>1,000 \mathrm{nM}$. Other mutations (e.g., rc8-TR $\beta 1$ ) required higher than normal $\mathrm{T} 3$ concentrations to bind coactivators and stimulate gene expression. Therefore, they may not be active in euthyreosis or hypothyreosis found in RCC patients. According to Rosen and Privalsky (35), these mutations were more likely to deregulate cell homeostasis in cells with specific co-repressor and co-activator variant expression. All the TR mutations may play specific roles in carcinogenesis, angiogenesis, and tumor progression mediated through the activity of target genes (38). Defects in the function of TRs may serve as a second hit, after VHL mutations, that triggers, or participates in, the transition from a renal cyst to a clear-cell carcinoma (34). As complement to cell line sequencing, our analysis of cBio Cancer Genomics Portal data showed that THRB gene is altered in 57 of 538 (10.6\%) ccRCC patients available for analysis (77,78). Identification of somatic copy-number alterations (SCNAs) driving cancer growth by GISTIC2.0 method (79) has shown that most common events reported in ccRCC are heterozygous deletion, followed by homozygous deletions and that gain of copy number is exceptional (Fig. 9). In the TCGA analysis of ccRCC, 15 of the 418 (3.6\%) cases described harbored deletions of THRB gene with majority of hemizygous deletions (32) suggesting that TR gene may be lost in RCC carcinogenesis, but it may also be mutated and be expressed as protein with novel transcription regulation functions.

In conclusion, we have shown that TR expression is deregulated in RCC cells, both in mRNA and protein level. RCC cells are also responsive to T3 stimulation and increase proliferation rate in most cases. Significant cell cycle shift towards $\mathrm{S}$ phase was apparent in RCC cancer stem cells. This could be one of the reasons why patients with hypothyreosis have better tumor shrinkage while treated with TKI. Nevertheless some tumors may be considered as T3-independent which may represent especially aggressive phenotype, where receptor is activated also in the absence of the ligand. On the contrary proliferation induced by deregulated VHL and or c-Met pathways may transgress normal T3 mediated regulation of the cell cycle.

\section{Acknowledgements}

This study was supported by Juventus PLUS project IP2011008171 [8736 0081/IP/2011/71] (head AMC). Medical English proofreading (Scribendi Inc., Canada) was covered by AMC.

\section{References}

1. Chen Y, Sun Y, Rao Q, Xu H, Li L and Chang C: Androgen receptor (AR) suppresses miRNA-145 to promote renal cell carcinoma (RCC) progression independent of VHL status. Oncotarget 6: 31203-31215, 2015.

2. King S, Bray S, Galbraith S, Christie L and Fleming S: Evidence for aldosterone-dependent growth of renal cell carcinoma. Int $\mathbf{J}$ Exp Pathol 95: 244-250, 2014.

3. Min KJ, Jang JH, Lee JT, Choi KS and Kwon TK: Glucocorticoid receptor antagonist sensitizes TRAIL-induced apoptosis in renal carcinoma cells through up-regulation of DR5 and downregulation of c-FLIP(L) and Bcl-2. J Mol Med (Berl) 90: 309-319, 2012. 
4. Poplawski P and Nauman A: Thyroid hormone - triiodothyronine - has contrary effect on proliferation of human proximal tubules cell line (HK2) and renal cancer cell lines (Caki-2, Caki-1) - role of E2F4, E2F5 and p107, p130. Thyroid Res 1: 5, 2008.

5. Mellemgaard A, From G, Jørgensen T, Johansen C, Olsen JH and Perrild $\mathrm{H}$ : Cancer risk in individuals with benign thyroid disorders. Thyroid 8: 751-754, 1998.

6. Prinzi N, Sorrenti S, Baldini E, De Vito C, Tuccilli C, Catania A, Coccaro C, Bianchini M, Nesca A, Grani G, et al: Association of thyroid diseases with primary extra-thyroidal malignancies in women: Results of a cross-sectional study of 6,386 patients. PLoS One 10: e0122958, 2015.

7. Videla LA, Fernández V, Cornejo P, Vargas R and Castillo I: Thyroid hormone in the frontier of cell protection, survival and functional recovery. Expert Rev Mol Med 17: e10, 2015

8. Shin DH, Lee MJ, Lee HS, Oh HJ, Ko KI, Kim CH, Doh FM, Koo HM, Kim HR, Han JH, et al: Thyroid hormone replacement therapy attenuates the decline of renal function in chronic kidney disease patients with subclinical hypothyroidism. Thyroid 23 : 654-661, 2013.

9. Katz AI, Emmanouel DS and Lindheimer MD: Thyroid hormone and the kidney. Nephron 15: 223-249, 1975.

10. Puzianowska-Kuznicka M, Pietrzak M, Turowska $\mathrm{O}$ and Nauman A: Thyroid hormones and their receptors in the regulation of cell proliferation. Acta Biochim Pol 53: 641-650, 2006.

11. Basu $\mathrm{G}$ and Mohapatra A: Interactions between thyroid disorders and kidney disease. Indian J Endocrinol Metab 16: 204-213, 2012.

12. Humes HD, Cieslinski DA, Johnson LB and Sanchez IO Triiodothyronine enhances renal tubule cell replication by stimulating EGF receptor gene expression. Am J Physiol 262: F540-F545, 1992.

13. Samad MA, Haque MM, Shah MK, Islam MR and Mia MC: Evaluation of TSH, T4 and T3 in human serum: Standardization on normal individuals American. J Mod Phys 2: 202-207, 2013.

14. Samuels HH and Tsai JS: Thyroid hormone action in cell culture: Domonstration of nuclear receptors in intact cells and isolated nuclei. Proc Natl Acad Sci USA 70: 3488-3492, 1973.

15. Maia AL, Goemann IM, Meyer EL and Wajner SM: Deiodinases: the balance of thyroid hormone: type 1 iodothyronine deiodinase in human physiology and disease. J Endocrinol 209: 283-297, 2011.

16. Niemczyk S, Dudek M, Bartoszewicz Z, Szamotulska K, Woźniacki L, Brodowska-Kania D, Niemczyk L, Małek W and Matuszkiewicz-Rowińska J: Determining the enzymatic activities of iodothyronine 5'-deiodinases in renal medulla and cortex. Endokrynol Pol 64: 182-185, 2013

17. Pachucki J, Ambroziak M, Tanski Z, Luczak J, Nauman J and Nauman A: Type I 5'-iodothyronine deiodinase activity and mRNA are remarkably reduced in renal clear cell carcinoma. J Endocrinol Invest 24: 253-261, 2001.

18. Rini BI, Tamaskar I, Shaheen P, Salas R, Garcia J, Wood L, Reddy S, Dreicer R and Bukowski RM: Hypothyroidism in patients with metastatic renal cell carcinoma treated with sunitinib. J Natl Cancer Inst 99: 81-83, 2007.

19. Tamaskar I, Bukowski R, Elson P, Ioachimescu AG, Wood L, Dreicer R, Mekhail T, Garcia J and Rini BI: Thyroid function test abnormalities in patients with metastatic renal cell carcinoma treated with sorafenib. Ann Oncol 19: 265-268, 2008

20. Schmidinger M, Vogl UM, Bojic M, Lamm W, Heinzl H, Haitel A, Clodi M, Kramer G and Zielinski CC: Hypothyroidism in patients with renal cell carcinoma: Blessing or curse? Cancer 117: 534-544, 2011.

21. Mousa SA, Lin HY, Tang HY, Hercbergs A, Luidens MK and Davis PJ: Modulation of angiogenesis by thyroid hormone and hormone analogues: Implications for cancer management. Angiogenesis 17: 463-469, 2014.

22. Liu X, Zheng N, Shi YN, Yuan J and Li L: Thyroid hormone induced angiogenesis through the integrin $\alpha_{1} \beta_{3}$ /protein kinase $\mathrm{D} /$ histone deacetylase 5 signaling pathway. J Mol Endocrinol 52 245-254, 2014

23. Davis PJ, Davis FB and Mousa SA: Thyroid hormone-induced angiogenesis. Curr Cardiol Rev 5: 12-16, 2009.

24. Borek C, Guernsey DL, Ong A and Edelman IS: Critical role played by thyroid hormone in induction of neoplastic transformation by chemical carcinogens in tissue culture. Proc Natl Acad Sci USA 80: 5749-5752, 1983.

25. Guernsey DL, Borek C and Edelman IS: Crucial role of thyroid hormone in X-ray-induced neoplastic transformation in cell culture. Proc Natl Acad Sci USA 78: 5708-5711, 1981.
26. Moeller LC and Führer D: Thyroid hormone, thyroid hormone receptors, and cancer: A clinical perspective. Endocr Relat Cancer 20: R19-R29, 2013.

27. Kim WG and Cheng SY: Thyroid hormone receptors and cancer. Biochim Biophys Acta 1830: 3928-3936, 2013.

28. Yalcin M,Bharali DJ,Lansing L, Dyskin E, Mousa SS, Hercbergs A, Davis FB, Davis PJ and Mousa SA: Tetraidothyroacetic acid (tetrac) and tetrac nanoparticles inhibit growth of human renal cell carcinoma xenografts. Anticancer Res 29: 3825-3831, 2009.

29. van der Hout AH, van der Vlies P, Wijmenga C, Li FP, Oosterhuis JW and Buys $\mathrm{CH}$ : The region of common allelic losses in sporadic renal cell carcinoma is bordered by the loci D3S2 and THRB. Genomics 11: 537-542, 1991.

30. Yokota J, Mori N, Akiyama T, Shimosato Y, Sugimura T and Terada M: Multiple genetic alterations in small-cell lung carcinoma. Princess Takamatsu Symp 20: 43-48, 1989.

31. Hu CY, Mohtat D, Yu Y, Ko YA, Shenoy N, Bhattacharya S, Izquierdo MC, Park AS, Giricz O, Vallumsetla N, et al: Kidney cancer is characterized by aberrant methylation of tissue-specific enhancers that are prognostic for overall survival. Clin Cancer Res 20: 4349-4360, 2014.

32. Network TCGAR; Cancer Genome Atlas Research Network: Comprehensive molecular characterization of clear cell renal cell carcinoma. Nature 499: 43-49, 2013.

33. Kamiya Y, Puzianowska-Kuznicka M, McPhie P, Nauman J, Cheng SY and Nauman A: Expression of mutant thyroid hormone nuclear receptors is associated with human renal clear cell carcinoma. Carcinogenesis 23: 25-33, 2002.

34. Rosen MD and Privalsky ML: Thyroid hormone receptor mutations in cancer and resistance to thyroid hormone: Perspective and prognosis. J Thyroid Res 2011: 361304, 2011.

35. Rosen MD and Privalsky ML: Thyroid hormone receptor mutations found in renal clear cell carcinomas alter corepressor release and reveal helix 12 as key determinant of corepressor specificity. Mol Endocrinol 23: 1183-1192, 2009.

36. Turowska O, Nauman A, Pietrzak M, Popławski P, Master A, Nygard M, Bondesson M, Tanski Z and PuzianowskaKuznicka M: Overexpression of E2F1 in clear cell renal cell carcinoma: A potential impact of erroneous regulation by thyroid hormone nuclear receptors. Thyroid 17: 1039-1048, 2007.

37. Nauman A, Turowska O, Poplawski P, Master A, Tanski Z and Puzianowska-Kuznicka M: Elevated cyclin E level in human clear cell renal cell carcinoma: Possible causes and consequences. Acta Biochim Pol 54: 595-602, 2007.

38. Rosen MD, Chan IH and Privalsky ML: Mutant thyroid hormone receptors (TRs) isolated from distinct cancer types display distinct target gene specificities: A unique regulatory repertoire associated with two renal clear cell carcinomas. Mol Endocrinol 25: 1311-1325, 2011.

39. Wojcicka A, Piekielko-Witkowska A, Kedzierska H, Rybicka B, Poplawski P, Boguslawska J, Master A and Nauman A: Epigenetic regulation of thyroid hormone receptor beta in renal cancer. PLoS One 9: e97624, 2014

40. Puzianowska-Kuznicka M, Nauman A, Madej A, Tanski Z, Cheng $S$ and Nauman J: Expression of thyroid hormone receptors is disturbed in human renal clear cell carcinoma. Cancer Lett 155: 145-152, 2000.

41. Master A, Wójcicka A, Piekiełko-Witkowska A, Bogusławska J, Popławski P, Tański Z, Darras VM, Williams GR and Nauman A: Untranslated regions of thyroid hormone receptor beta $1 \mathrm{mRNA}$ are impaired in human clear cell renal cell carcinoma. Biochim Biophys Acta 1802: 995-1005, 2010.

42. Ebert T, Bander NH, Finstad CL, Ramsawak RD and Old LJ: Establishment and characterization of human renal cancer and normal kidney cell lines. Cancer Res 50: 5531-5536, 1990.

43. Tanaka T, Torigoe T, Hirohashi Y, Sato E, Honma I, Kitamura H, Masumori N, Tsukamoto T and Sato N: Hypoxia-inducible factor (HIF)-independent expression mechanism and novel function of HIF prolyl hydroxylase-3 in renal cell carcinoma. J Cancer Res Clin Oncol 140: 503-513, 2014

44. Gati A, Da Rocha S, Guerra N, Escudier B, Moretta A, Chouaib S, Angevin E and Caignard A: Analysis of the natural killer mediated immune response in metastatic renal cell carcinoma patients. Int J Cancer 109: 393-401, 2004.

45. Beck-Peccoz P, Chatterjee VK, Chin WW, DeGroot LJ, Jameson JL, Nakamura H, Refetoff S, Usala SJ and Weintraub BD: Nomenclature of thyroid hormone receptor beta-gene mutations in resistance to thyroid hormone: Consensus statement from the first workshop on thyroid hormone resistance, July 10-11, 1993, Cambridge, United Kingdom. J Clin Endocrinol Metab 78: 990-993, 1994. 
46. Sakurai A, Nakai A and DeGroot LJ: Structural analysis of human thyroid hormone receptor beta gene. Mol Cell Endocrinol 71: 83-91, 1990.

47. Curran PJ, Obeidat $\mathrm{K}$ and Losardo D: Twelve frequently asked questions about growth curve modeling. J Cogn Dev 11: 121-136, 2010.

48. Yuan JS, Reed A, Chen F and Stewart CN Jr: Statistical analysis of real-time PCR data. BMC Bioinformatics 7: 85, 2006.

49. Hoch FL: Biochemistry of hyperthyroidism and hypothyroidism. Postgrad Med J 44: 347-362, 1968.

50. Ohba K, Takayama T, Matsunaga H, Matsushita A, Sasaki S, Oki Y, Ozono S and Nakamura H: Inappropriate elevation of serum thyrotropin levels in patients treated with axitinib. Thyroid 23: 443-448, 2013.

51. Bozkurt O, Karaca H, Hacibekiroglu I, et al: Is sunitinib-induced hypothyroidism a predictive clinical marker for better response in metastatic renal cell carcinoma patients? J Chemother 1973947815 Y0000000039, 2015.

52. Riesenbeck LM, Bierer S, Hoffmeister I, Köpke T, Papavassilis P, Hertle L, Thielen B and Herrmann E: Hypothyroidism correlates with a better prognosis in metastatic renal cancer patients treated with sorafenib or sunitinib. World J Urol 29: 807-813, 2011.

53. Nearchou A, Valachis A, Lind P, Akre O and Sandström P. Acquired hypothyroidism as a predictive marker of outcome in patients with metastatic renal cell carcinoma treated with tyrosine kinase inhibitors: A literature-based meta-analysis. Clin Genitourin Cancer 13: 280-286, 2015.

54. Krenning EP, Docter R, Visser TJ and Hennemann G: The significance of plasma membrane transport of iodothyronines in the regulation of thyroid hormone bioavailability. Acta Med Austriaca 15 (Suppl 1): 15-17, 1988.

55. Samuels HH, Tsai JS and Cintron R: Thyroid hormone action: A cell-culture system responsive to physiological concentrations of thyroid hormones. Science 181: 1253-1256, 1973.

56. Yen PM: Physiological and molecular basis of thyroid hormone action. Physiol Rev 81: 1097-1142, 2001.

57. Cunha Lima ST and Rodrigues ED: The oligomeric state of thyroid receptor regulates hormone binding kinetics. J Endocrinol 210: 125-134, 2011.

58. Capasso G, De Santo NG and Kinne R: Thyroid hormones and renal transport: Cellular and biochemical aspects. Kidney Int 32: 443-451, 1987.

59. Trachtman H, Jacques C, Citron J and Futterweit S: Effect of triiodothyronine on nitric oxide production in mesangial cells and renal tubular epithelial cells. Res Commun Mol Pathol Pharmacol 93: 69-78, 1996.

60. Ward HH, Romero E, Welford A, Pickett G, Bacallao R, Gattone VH II, Ness SA, Wandinger-Ness A and Roitbak T: Adult human CD133/1(+) kidney cells isolated from papilla integrate into developing kidney tubules. Biochim Biophys Acta 1812: 1344-1357, 2011.

61. Choi JW and Choi HS: The regulatory effects of thyroid hormone on the activity of 3-hydroxy-3-methylglutaryl coenzyme A reductase. Endocr Res 26: 1-21, 2000.

62. Moeller LC, Wardrip C, Niekrasz M, Refetoff S and Weiss RE: Comparison of thyroidectomized calf serum and stripped serum for the study of thyroid hormone action in human skin fibroblasts in vitro. Thyroid 19: 639-644, 2009.

63. Alini M, Kofsky Y, Wu W, Pidoux I and Poole AR: In serum-free culture thyroid hormones can induce full expression of chondrocyte hypertrophy leading to matrix calcification. J Bone Miner Res 11: 105-113, 1996.
64. de Oliveira M, Luvizotto RA, Olimpio RM, De Sibio MT, Conde SJ, Biz Rodrigues Silva C, Moretto FC and Nogueira CR: Triiodothyronine increases mRNA and protein leptin levels in short time in 3T3-L1 adipocytes by PI3K pathway activation. PLoS One 8: e74856, 2013.

65. Reynolds AM, Surks MI and Shapiro LE: The effects of chronic exposure to supraphysiological concentrations of 3, 5, 3' triiodoL-thyronine (T3) on cultured GC cells. J Cell Physiol 149: 544-547, 1991.

66. Ryan MJ, Johnson G, Kirk J, Fuerstenberg SM, Zager RA and Torok-Storb B: HK-2: An immortalized proximal tubule epithelial cell line from normal adult human kidney. Kidney Int 45: 48-57, 1994.

67. Wang WM, Chung MH and Huang SM: Regulation of nuclear receptor activities by two human papillomavirus type 18 oncoproteins, E6 and E7. Biochem Biophys Res Commun 303: 932-939, 2003.

68. Wu MH, Huang CJ, Liu ST, Liu PY, Ho CL and Huang SM: Physical and functional interactions of human papillomavirus E2 protein with nuclear receptor coactivators. Biochem Biophys Res Commun 356: 523-528, 2007.

69. Bens $M$ and Vandewalle A: Cell models for studying renal physiology. Pflugers Arch 457: 1-15, 2008.

70. Simonides WS, Mulcahey MA, Redout EM, Muller A, Zuidwijk MJ, Visser TJ, Wassen FW, Crescenzi A, da-Silva WS, Harney J, et al: Hypoxia-inducible factor induces local thyroid hormone inactivation during hypoxic-ischemic disease in rats. J Clin Invest 118: 975-983, 2008.

71. Foster DA, Yellen P, Xu L and Saqcena M: Regulation of G1 cell cycle progression: Distinguishing the restriction point from a nutrient-sensing cell growth checkpoint(s). Genes Cancer 1: 1124-1131, 2010.

72. Cooper S: On the interpretation of the shortening of the G1-phase by overexpression of cyclins in mammalian cells. Exp Cell Res 238: 110-115, 1998.

73. Pernitsky AN and Anderson JE: Differential effects of 3,5,3'-triiodothyronine on control and mdx myoblasts and fibroblasts: Analysis by flow cytometry. Exp Cell Res 227: 214-222, 1996.

74. Maruvada P, Dmitrieva NI, East-Palmer J and Yen PM: Cell cycle-dependent expression of thyroid hormone receptor-beta is a mechanism for variable hormone sensitivity. Mol Biol Cell 15: 1895-1903, 2004.

75. Lin YC, Boone M, Meuris L, Lemmens I, Van Roy N, Soete A, Reumers J, Moisse M, Plaisance S, Drmanac R, et al: Genome dynamics of the human embryonic kidney 293 lineage in response to cell biology manipulations. Nat Commun 5: 4767, 2014.

76. Jansson M, Philipson L and Vennström B: Isolation and characterization of multiple human genes homologous to the oncogenes of avian erythroblastosis virus. EMBO J 2: 561-565, 1983.

77. Cerami E, Gao J, Dogrusoz U, Gross BE, Sumer SO, Aksoy BA, Jacobsen A, Byrne CJ, Heuer ML, Larsson E, et al: The cBio cancer genomics portal: An open platform for exploring multidimensional cancer genomics data. Cancer Discov 2: 401-404, 2012.

78. Gao J, Aksoy BA, Dogrusoz U, Dresdner G, Gross B, Sumer SO, Sun Y, Jacobsen A, Sinha R, Larsson E, et al: Integrative analysis of complex cancer genomics and clinical profiles using the cBioPortal. Sci Signal 6: pl1, 2013.

79. Mermel CH, Schumacher SE, Hill B, Meyerson ML, Beroukhim R and Getz G: GISTIC2.0 facilitates sensitive and confident localization of the targets of focal somatic copy-number alteration in human cancers. Genome Biol 12: R41, 2011. 